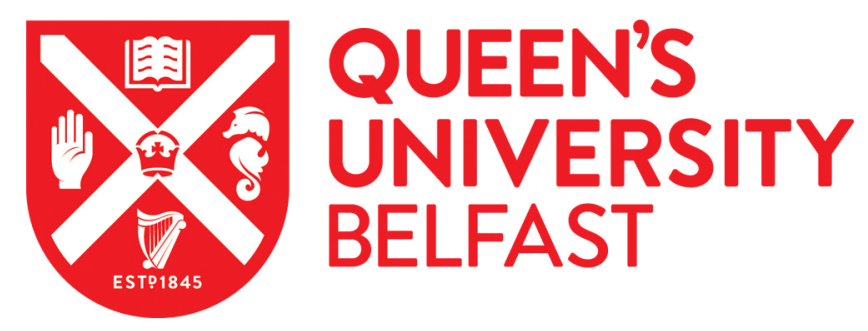

\title{
The distribution of novel bacterial laccases in alpine paleosols is directly related to soil stratigraphy
}

Dandare, S., Young, J. M., Kelleher, B. P., \& Allen, C. (2019). The distribution of novel bacterial laccases in alpine paleosols is directly related to soil stratigraphy. Science of the Total Environment, 671, 19-27.

Published in:

Science of the Total Environment

Document Version:

Peer reviewed version

Queen's University Belfast - Research Portal:

Link to publication record in Queen's University Belfast Research Portal

Publisher rights

(c) 2019 Elsevier B. V.

This manuscript version is made available under the CC-BY-NC-ND 4.0 license http://creativecommons.org/licenses/by-nc-nd/4.0/,which permits distribution and reproduction for non-commercial purposes, provided the author and source are cited.

\section{General rights}

Copyright for the publications made accessible via the Queen's University Belfast Research Portal is retained by the author(s) and / or other copyright owners and it is a condition of accessing these publications that users recognise and abide by the legal requirements associated with these rights.

Take down policy

The Research Portal is Queen's institutional repository that provides access to Queen's research output. Every effort has been made to ensure that content in the Research Portal does not infringe any person's rights, or applicable UK laws. If you discover content in the Research Portal that you believe breaches copyright or violates any law, please contact openaccess@qub.ac.uk. 


\section{The distribution of novel bacterial laccases in alpine paleosols}

\section{2 is directly related to soil stratigraphy.}

4 S.U. Dandare ${ }^{1}$, J.M. Young ${ }^{1}$, B.P. Kelleher ${ }^{2}$, C.C.R. Allen ${ }^{* 1,3}$

$5 \quad{ }^{1}$ School of Biological Sciences, Queen's University Belfast, UK

$6 \quad{ }^{2}$ School of Chemical Sciences, Dublin City University, Ireland

$7 \quad{ }^{3}$ Institute for Global Food Security, Queen's University Belfast, UK

$8 \quad *$ Corresponding author

\section{$9 \quad$ ABSTRACT}

Bacterial laccases are now known to be abundant in soil and to function outside of the cell facilitating

11 the bacterial degradation of lignin. In this study we wanted to test the hypotheses that: i) Such enzymes can be identified readily in stratified paleosols using metagenomics approaches, ii) The distribution of these genes as potential 'public good' proteins in soil is a function of the soil environment, iii) Such laccase genes can be readily retrieved and expressed in E.coli cloning systems to demonstrate that de novo assembly processes can be used to obtain similar metagenome-derived enzyme activities. To test these hypotheses, in silico gene-targeted assembly was employed to identify genes encoding novel typeB two-domain bacterial laccases from alpine soil metagenomes sequenced on an Illumina MiSeq sequencer. The genes obtained from different strata were heterologously cloned, expressed and the gene products were shown to be active against two classical laccase substrates. The use of a metagenome-driven pipeline to obtain such active biocatalysts has demonstrated the potential for gene mining to be applied systematically for the disccovery of such enzymes. These data ultimately further demonstrate the application of soil pedology methods to 
environmental enzyme discovery. As an interdisciplinary effort, we can now establish that palesols can serve as a useful source of novel biocatalytic enzymes for various applications. We also, for the first time, link soil stratigraphy to enzyme profiling for widespread functional gene activity in paleosols.

27 1. INTRODUCTION

Laccases are oxidoreductase enzymes which can act upon a broad range of phenolic and non-phenolic compounds via the reduction of molecular oxygen to $\mathrm{H}_{2} \mathrm{O}$. Consequently, they have many applications as 'green' biocatalysts in varied industries - including textile and dye decolourisation, bioremediation, pulp bio-bleaching, microbial fuel cells and biosensors (Couto et al., 2006). The advent of high throughput sequencing and associated metagenomics has revealed that bacteria possess a huge diversity of laccase-like multicopper-oxidases (LMCOs) genes. Many of these appear to possess $\mathrm{N}$ terminal signal peptide sequences (Ausec et al., 2011), suggesting they are secreted by the cell, potentially enabling oxidation of lignin-derived compounds outside the cell. Only a few bacterial LMCOs have been purified and characterised to date; however, data from these studies suggests unique and biotechnologically advantageous properties, including chloride tolerance (Guan et al., 2014), increased stability at extremes of pH and temperature (Chanuhan and Jha, 2018, Fang et al., 2011) and ionic liquid tolerance (Chauhan et al., 2018). Soils are the primary site of terrestrial organic carbon degradation and are some of the most genetically diverse environments on earth (Torsvik 1990). Despite this, very little is known about both the abundance and distribution of Bacterial LMCO's in the soil.

Bacterial laccases can be divided into several categories based upon sequence similarity, the number of cupredoxin domains they possess and their tertiary structure (Ausec et al., 2011). Type B and C two domain laccases are homotrimeric proteins with each monomer consisting of two cupredoxin domains (Martins et al., 2015). By contrast, three-domain bacterial laccases are monomeric and can be 
47 subdivided into three categories based upon sequence similarity, 'small' three domain laccases, 'big' three domain laccases and CotA type laccase (similar to cotA from B. subtilis). Most Bacterial laccases which have been heterologously expressed and characterised to date are three domain type laccases (Martins et al., 2015), and recombinant three-domain Laccases have found widespread industrial usage.

There is presently considerable interest in the degradation of lignin in diverse environments, where different microorganisms compete for lignin and lignin breakdown products (Cragg et al., 2015). However, fundamental questions about the distribution of lignin-degrading bacteria are evident: Do different types of lignin degrading bacteria exist in competing or cooperative bacterial communities? How do these bacteria exist alongside the lignin-degrading fungi? Do various types of extracellular lignin-degrading 'common good' proteins (such as peroxidases and laccases) exhibit functional variation that is related to the environmental niche where they are found as opposed to their phylogenetic origin? Analysis of soil metagenomes may help us to answer some of these questions (Jacquiod et al., 2014). Further gene-mining approaches can be used to retrieve functional laccases from soil metagenomes also (Yang et al., 2018). In this study, we used a metagenome analysis of genes for bacterial laccase enzymes in an alpine paleosol. In bacteria, laccases have differing functionalities: whereas some enzymes are clearly associated with non-catabolic roles, such as endospore germination in Firmicutes and are not known to be secreted from the cell (Francisco et al., 2004); others (e.g. the two-domain group of bacterial laccases) appear to play an extracellular function. Here we took samples from Alpine paleosols (Mahaney et al., 2016) that we know have well-defined stratigraphy, with the inceptisols harbouring distinct Ah, Bw and Cox soil horizons. We then tested the hypothesis that there is a differential distribution of the major well-defined groups of functional bacterial laccases across these horizons, which are therefore affected by changing physical and chemical environmental conditions. By investigating the demarcation of different classes of laccase 
gene across paleosol soil horizon boundaries, we sought to show for the first time that the different environments present in these soil environments could affect the molecular ecology of such genes and therefore that their functionality could be linked to their ecological niche.

In validating these core questions, we also wanted to show that the two-domain group of bacterial laccases can be cloned and expressed for biochemical analysis when directly derived from such soil metagenome sources.

\section{MATERIALS AND METHODS}

79

80

\section{Materials}

The substrates 2, 2' - Azino-bis (3-ethylbenzothiazoline-6-sulfonate) (ABTS) and syringaldazine (SGZ) were products obtained from Sigma-Aldrich (St. Louis, MO, USA). Mo Bio Powersoil DNA extraction kit was obtained from Qiagen. Gel Extraction Kit, Plasmid Mini-Prep Kit, Dream Taq DNA polymerase, Phusion green DNA polymerase, ClonJET cloning kit, aLicator LIC cloning and expression system, SYBR Green qPCR Master Mix, prestained protein ladder, and the TOP10 chemically competent $E$. coli cells were all purchased from Thermo Fisher Scientific (UK). The BL21 (DE3) chemically competent cells were purchased from New England Biolabs, while the restriction enzymes were obtained from Fermentas. All other chemicals used in this study were of analytical reagent grade.

\section{Sampling sites}

Soils samples used in the study were as previously described: vertical profiles of soil from a series of glacial moraines in the Guil river valley in the French Alps, (G1, G2, G3a, G9, and G11) and the Po river valley in the Italian Alps (V10) were sampled by their soil horizon classification (Mahaney et al., 2016). 

is reproduced in the supplementary section (S6) from Young et al. (2019). Briefly, samples were collected from the mid-point depth of soil horizon profiles for specific horizons (e.g. Ah, Bw, Cox). So for a soil horizon of $5 \mathrm{~cm}$ depth, samples were collected $2.5 \mathrm{~cm}$ into the horizon. The aim was to obtain samples that were representative of each horizon. Samples were collected using sterile implements and storage vials. They were immediately stored on ice, in the dark, throughout transport to the laboratory. They were then frozen at $-20^{\circ} \mathrm{C}$ before further analysis.

\section{Metagenomic library construction}

102

103

DNA was extracted from alpine paleosol samples using a PowerSoil DNA extraction kit (Mo Bio). For each extraction $0.25 \mathrm{~g}$ of soil was used, extractions were performed in triplicate for each sample and pooled. Extractions were performed according to the manufacturer's protocol with the following modifications: samples were homogenised using a FastPrep 120 cell disrupter system (Thermo-Fisher) at $5.5 \mathrm{~m} . \mathrm{s}^{-1}$ for 2 minutes, rather than a standard benchtop vortex. The eluted DNA was further purified via two rounds of ethanol precipitation; DNA solution was suspended in 3 volumes of ice-cold $100 \%$ ethanol, 0.1 volumes $5 \mathrm{M}$ sodium acetate solution ( $\mathrm{pH} 5.2$ ) and $2 \mu \mathrm{L}$ of linear polyacrylamide (LPA), the solution was then incubated overnight at $-20^{\circ} \mathrm{C}$ and centrifuged at $18000 \times \mathrm{g}$ at $4^{\circ} \mathrm{C}$ for 30 minutes. The supernatant was discarded, and the pellet washed in $70 \%$ ice-cold ethanol and again centrifuged at $18000 \times \mathrm{g}$ at $4^{\circ} \mathrm{C}$ for 5 minutes. Finally, the supernatant was discarded and the pellet allowed to air dry for 15 minutes before resuspension in $50 \mu \mathrm{L}$ molecular grade $\mathrm{H}_{2} \mathrm{O}$. Final DNA concentrations were measured using a Quantus Fluorometer (Promega) in conjunction with the Quantiflour dsDNA dye system (Promega).

DNA sequencing libraries for Illumina sequencing prepared using a Nextera NX library preparation kit (Illumina), DNA libraries were sequenced on an Illumina MiSeq DNA sequencer in the paired-end mode for 300 cycles. Library preparation and sequencing were performed at the University of Cambridge 
DNA sequencing facility. Raw Sequence data files are available in the NCBI sequence read archive under Bioproject number PRJNA39461.

\section{Metagenomic library screening and sequence analysis}

Raw reads were quality trimmed to a minimum mean quality of 20 over a sliding window of 10 bases using bbduk from the bbmap package (Bushnell, 2015). Reads from all 18 samples were co-assembled using Megahit (Li et al., 2016), contigs < $1 \mathrm{kbp}$ were discarded, and open reading frames were identified and extracted using Prodigal (Hyatt et al., 2010) with the -meta flag. Resulting in a library of 1154087 ORFs. Putative bacterial laccase sequences were classified from this library of ORFs using previously published profile hidden Markov models for bacterial laccases (Ausec et al., 2011). Only hits with an e-value $<1$-10 were retained, these were manually checked against the NCBI conserved domain database to ensure they possessed the cupredoxin domain characteristic of laccases. The final library of laccases was taxonomically classified using Kaiju (Menzel et al., 2016), against a database of all proteins from all bacteria, archaea, single-celled eukaryotes and viruses in the NCBI non-redundant protein database (NCBI Resource Coordinators, 2017). Raw reads were mapped onto the library of putative laccase genes using bbmap with the flags with the flags $k=13$ vslow=t. Normalised relative abundances were calculated as TPMS (transcripts per million) as this is the most robust and appropriate method for comparisons of gene sets between samples described by Wagner et al. (2012) and is applicable to metagenomic as well as RNA-Seq data.

In order to isolate novel type B two-domain laccase for downstream expression and characterisation, primers were designed for three type-B two-domain laccases for which an entire ORF including upstream ribosomal binding site was captured in the assembly (supplementary data S1). However, only one of these primer sets yielded PCR products (mg_lacc_fw: 5'-ATGAGCAATAGACGTGGCTT-3', mg_lac_rev: 5'-ATTCATGTTTGTGCTCCATCTC-3').

PCR was performed using these primers with total extracted DNA from the three Viso 10 site samples, with the following conditions: initial denaturation $95^{\circ} \mathrm{C}$ for 3 minutes; denaturation $95^{\circ} \mathrm{C}$ for 30 
seconds; annealing $53^{\circ} \mathrm{C}$ for 90 seconds; extension $72^{\circ} \mathrm{C}$ for 1 minute; final extension $72^{\circ} \mathrm{C}$ for 7 min; 30 cycles. DNA gel electrophoresis confirmed fragments of the expected size (1500bp), these were excised from the gel and purified using a GeneJET gel extraction kit (Thermo-Fisher). Purified PCR products were ligated into PJET 1.2/blunt vector using a CloneJET PCR cloning kit (Thermo-Fisher), and transformed into E.Coli BL21 (DE3) competent cells by heat shock transformation. Transformed clones were grown overnight on $100 \mu \mathrm{g} \mathrm{mL}$ ampicillin LB agar plates at $30^{\circ} \mathrm{C}$. Individual colonies were selected and grown overnight in $100 \mu \mathrm{g} \mathrm{m}^{-1}$ ampicillin LB broth, Plasmids were extracted from each broth culture using a GeneJET plasmid extraction kit (Thermo-scientific), extracted plasmids were sequenced using an Applied Biosystems 3730 DNA analyser at the University of Dundee DNA sequencing facility, yielding a final library of 8 sequenced PCR products of the expected insert size.

\section{Statistical analysis of data}

Metagenome sequence data were analysed using the same methods to those described in our earlier report - the identical metagenome dataset was used in the present study (Young et al., 2019). Statistical analysis were carried out in R version 3.4.1 (R CoreTeam, 2011), running on an Ubuntu 16.04 LTS PC with 16 GB RAM and an Intel core i7

$6700 \mathrm{~K}$ processor. The reader is referred to our earlier study for details of methodology used. the BASE R: kruskal test package (R Core Team, 2011, Kruskaland Wallis, 1952).

The analysis of 26 abiotic variables - previously described by Mahaney et al. (2016) -a Euclidean distance dissimilarity matrix of soil geochemical variables was produced using the package Vegan (Dixon, 2003) in R. v3.4.1 [R Core Team, 2011] using permutational analysis of variance. Principle component analysis was performed on this matrix using the vegan function cap scale, twodimensional ordination plots were produced using the first two principle components as axes. For 
Figure 3 and references in the legend). The laccase genes identified in each sample were annotated using the package Kaiju (Menzel et al., 2016). Statistical analysis of each enzyme subgroup across the metagenome datasets was performed using Kruskal-Wallis one way ANOVA (Kruskal \& Wallis, 1952).

Maximum likelihood phylogenetic trees were drawn using Mega 7.0 (Kumar et al., 2016). The reference sequences shown were downloaded from the NCBI database. Cloning and heterologous expression of novel laccase genes

173 The laccase genes were then sub-cloned into pLATE11 (untagged) ligation independent cloning (LIC) and expression vector without their signal peptides. Genes without their signal peptides were obtained by designing new forward primers that excluded the 26 amino acids $\mathrm{N}$-terminal signal peptide during amplification. The pJET 1.2/blunt plasmids containing laccase genes were used as the templates for amplification of laccase genes without their signal peptides. Each Lac-pLATE11 recombinant was transformed into $E$. coli BL21 (DE3), and transformants were selected on LB agar plates supplemented with $100 \mu \mathrm{g} \mathrm{mL} \mathrm{L}^{-1}$ ampicillin.

For the expression of recombinant laccases, LB ( $5 \mathrm{~g} \mathrm{~L}^{-1}$ yeast extract, $10 \mathrm{~g} \mathrm{~L}^{-1}$ tryptone, $\left.5 \mathrm{~g} \mathrm{~L}^{-1} \mathrm{NaCl}\right)$ medium was used (Bertani, 1951). Expression studies were performed in shake flasks; each culture was inoculated with individual overnight pre-cultures (grown at $30^{\circ} \mathrm{C}, 140 \mathrm{rpm}$ ) and incubated at 30 ${ }^{\circ} \mathrm{C}$ and $160 \mathrm{rpm}$ until the cells grew to a mid-exponential phase $\left(\mathrm{OD}_{600} \approx 0.6\right)$. At mid-growth phase, the temperature and rotation speed were downshifted to $25^{\circ} \mathrm{C}$ and $100 \mathrm{rpm}$ respectively; and the addition of $0.1 \mathrm{mM}$ IPTG induced the expression of recombinant laccases. The culture was also supplemented with copper ions in the form of $\mathrm{CuSO}_{4}$ to a final concentration of $0.25 \mathrm{mM}$. Oxygenlimiting condition (microaeration) was introduced by switching off rotation ( $0 \mathrm{rpm}) 4 \mathrm{~h}$ after induction; static incubation has been reported to increase the amount of copper-loaded bacterial laccases in $E$. coli (Durão et al., 2008). The static incubation was maintained for $20 \mathrm{~h}$, and then cells were harvested by centrifugation (6000 rpm, $15 \mathrm{~min}$ ). The recovered cell pellets were frozen at $-80^{\circ} \mathrm{C}$. 
In order to recover the proteins, cells were thawed and lysed by resuspending in Cellytic B solution

192 (Sigma-Aldrich) containing $0.5 \mathrm{U} \mathrm{mL}^{-1}$ Benzonase Nuclease (Novagen) and $0.2 \mathrm{mg} \mathrm{mL}^{-1}$ lysozyme. The mixture was incubated at room temperature with shaking $(200 \mathrm{rpm})$ for $20 \mathrm{~min}$ according to manufacturer's instructions. After the soluble fraction was separated from the cell debris by centrifugation ( $18000 \times \mathrm{g}, 15 \mathrm{~min}$ ), it was heated at $70^{\circ} \mathrm{C}$ for $15 \mathrm{~min}$ to precipitate most of the $E$. coli proteins as a form of partial purification. The thermal activation of laccases has been reported in several studies (Mollania et al., 2018; Papinutti et al., 2008; Koroleva et al., 2001). Samples collected throughout the expression studies including the cell-free extract (CFE) were mixed 1:1 with SDS-PAGE loading buffer, denatured at $95^{\circ} \mathrm{C}$ for $5 \mathrm{~min}$, and electrophoresed on a 10\% SDS-PAGE resolving gel. The concentration of protein was estimated using the Bradford assay with bovine serum albumin (BSA) as the standard.

\section{Enzyme assay}

The activity of laccases was measured at $25^{\circ} \mathrm{C}$ using ABTS $\left(\varepsilon_{420 \mathrm{~nm}}=36 \mathrm{mM}^{-1} \mathrm{~cm}^{-1}\right)$ and syringaldazine $\left(\varepsilon_{530 \mathrm{~nm}}=65 \mathrm{mM}^{-1} \mathrm{~cm}^{-1}\right)$ as substrates with a $6705 \mathrm{UV} / \mathrm{Vis}$ spectrophotometer (Jenway). Each assay mixture was made up to $1 \mathrm{~mL}$ and contained $2 \mathrm{mM}$ ABTS (dissolved in phosphate buffer) or $0.05 \mathrm{mM}$ SGZ (dissolved in absolute methanol), $100 \mu \mathrm{L}$ of cell-free extract (CFE) and phosphate buffer at $\mathrm{pH} 4.0$ or pH 6.5 for ABTS and SGZ assays respectively. The fungal laccase from Trametes versicolor (Sigma Aldrich) was used as a positive control while cell-free extract prepared from an expression experiment with an empty vector was used as a negative control. The oxidation of both ABTS and SGZ was followed by a change in absorbance at $420 \mathrm{~nm}$ and $530 \mathrm{~nm}$ respectively for $10 \mathrm{~min}$. One unit (U) of laccase activity was defined as the amount of laccase required to oxidise $1 \mu \mathrm{mol}$ of substrate per minute (1 $\left.\mu \mathrm{mol} \mathrm{min}^{-1}\right)$. All assays were performed in triplicate. 
3.1THE STRATIGRAPHY OF SAMPLING SITES IS CONSISTENT WITH SOIL HORIZONS REPRESENTING DISTINCT SETS OF ENVIRONMENTAL PARAMETERS THAT ARE INDEPENDENT OF GEOGRAPHIC

Previous studies at this site in the Guil valley and Mount Viso region have classified the sampled paleosols as inceptisols with specific soil pedons as defined in the geological literature (Mahaney et al., 2016; Young et al., 2019). While there is a long established convention of describing glacial sediment deposits in terms of $\mathrm{Ah}, \mathrm{Bw}, \mathrm{Cox}, \mathrm{Cu}$, and $\mathrm{D}$ horizons - based upon variation in physical and chemical distinctions down the soil profile - there is no detailed attempt to date, to link differences in extra-cellular microbial enzyme distribution to this classification.

We initially used data gathered in an earlier paper (Mahaney et al., 2016) to show that the 27 chemical and physical parameters previously measured in each of the 18 samples -6 each being designated as Ah, Bw and Cox - did indeed indicate that soil Horizons represent distinct physical/chemical environments. Soil horizons were chemically and physically distinct as indicated by Principle Coordinates Analysis, wherein the first two principle co-ordinate axes explained over $70 \%$ of the total variation between samples (Figure 1).

\subsection{THE DISTRIBUTION OF BACTERIAL LACCASE GENES IS RELATED TO SOIL STRATIGRAPHY}

We searched a library of 1154088 ORFs from all the paleosol samples sequenced from a metagenomic co-assembly of 135365644 raw reads for putative bacterial laccases using previously published profile hidden Markov models for bacterial laccases (Ausec et al., 2011), resulting in 323 new putative laccaselike ORFs being identified. Of these, there were many that include both start and stop codons. The amino acid translation of these sequences were additionally aligned against the NCBI $\mathrm{nr}$ protein 
similarity to known LMCO genes [supplementary data table S2]. This analysis highlighted the abundance of novel LMCO sequences in these soils.

We hypothesised that the abundances of different classes of bacterial laccases would vary significantly between stratified soil horizons, as their functional role as extracellular biocatalysts would inevitably be linked to localised environmental parameters. In order to test this hypothesis, we applied Kruskal Wallace one way ANOVA (Kruskal \& Wallis, 1952) to the relative abundance of putative laccases grouped by soil horizon (Figure 2), revealing that all but two classes of bacterial laccases vary significantly in abundance between soil horizon. The type B two domain laccases appear to increase in abundance down a soil profile and show the strongest variation with soil horizon, while the big three domain, small three-domain and CotA -type laccases all decrease in abundance with soil depth. It should be noted that, in terms of relative abundance, the two most abundant classes of enzyme in these samples are the small three-domain and type B two domain laccases (Figure 3). These two groups comprise $>70 \%$ of all laccase-like genes identified.

The predicted taxonomic affiliations for putative laccase ORFs shows strikingly different community structures between laccase types (Supplementary Figure S4). Additionally, principal coordinate analysis of the predicted taxonomic affiliations shows clear differences between the Ah Horizon and Bw/Cox horizons for the type B two domain, small three domain and CotA type laccases (Figure 3). Indicating that the distribution of laccase genes in the soil horizons is affected by the soil horizon location as well as by the phylogeny of any expressing bacterial cell. Critically, the two most abundant groups of identified genes show the greatest demarcation between soil horizons in these PCA plots. Where relatively few genes were identified in the horizons (e.g. the 'Big 3D' group) there is no clear demarcation. It is important to note here that given the fragmented nature of the assembly from which these ORFs were derived, that we cannot deduce which organisms may be harbouring multiple laccase gene types, although such organisms should certainly exist. 

complete ORF including start and stop codons, as well as a signal peptide (indicating potential extracellular secretion), could be identified. These primers were all tested against multiple samples from the paleosols, to see if laccases could be readily amplified. We found only one set of primers gave reliable amplification and only when using DNA extracted from the V10 Bw and Cox samples. These primers were designated [V10_lac]. Cloning and sequencing of these PCR products yielded eight high-quality sequences of the expected insert size; these showed high homology with the assembled parent sequence; these sequences are compared in a phylogenetic tree (Figure 5). Interestingly, none of the PCR amplified sequences were $100 \%$ identical to the parent sequence, this may be attributed to the fact that a contiguous sequence derived from a typical metagenomic assembly is often a consensus sequence of closely related strains and variants present in the dataset, other factors may be involved including PCR error, variants introduced during exponential growth of the cloning vectors and sequencing error (both Illumina and Sanger sequencing). Despite this, in this case, it appears that the assembled gene sequence was sufficiently accurate to allow the design of PCR primers which could be used to isolate functionally active proteins from a portion of the soil samples.

\subsection{Characterisation of cloned laccases}

There is a limited detailed biochemical analysis of two domain laccase enzymes from Acidobacteria in the literature, despite the importance of these bacteria in soil (Jones et al., 2009). Further, there is just one account of a metagenome laccase analysed to date (Ausec et al., 2017). To validate the metagenomic enzyme discovery pipeline used in this study, we selected four Acidobacteria twolike activity for the identified gene products. 
In all the laccases tested, the enzymes showed higher activity against SGZ than ABTS (Figure 6). This observation has been made with other laccases (Guan et al., 2014; Lu et al., 2013; Ye et al., 2010). Also, enzymes mined from the Bw horizon (LacB3 and LacB6) showed more activity against both substrates tested than enzymes from the C horizon (LacC12 and LacC15).

This experiment confirmed that complete functional genes for the typeB $2 \mathrm{D}$ group could be isolated from the paleosols. It effectively validated both the use of our metagenomics methods for novel laccase gene discovery and complete gene isolation, from these paleosols. It also validated the designation of our metagenome analysis methods for the identification of putative laccase genes.

Further experimentation confirmed that these enzymes were in fact functionally distinct laccases. For example, copper dependence is a key characteristic of laccases, and we showed that one of the enzymes (LacB6, that had the highest activity with both substrate of the four clones) required $\mathrm{CuSO}_{4}$ addition for full activity (Figure 7). We also showed that the activity of LacB6 against syringaldazine increased with increasing concentration of copper. The addition of 10-, 50- and $100 \mu \mathrm{M} \mathrm{CuSO}{ }_{4}$ in the assay mix increased the enzyme activity $2.5-, 5$, and 8-fold respectively. These observations confirm that LacB6 is a copper-dependent enzyme and that copper was only partially incorporated into the enzyme's active site during expression. Cloned and expressed laccases are usually partially copperdepleted as a result of the difficulty of the passage of copper ions from the medium into the cell during expression (Harris, 2000; Vulpe and Packman, 1995).

Molecular modelling was performed on the Laccase_B_6 amino acid sequence using three publically available protein modelling servers, ITASSER (https://zhanglab.ccmb.med.umich.edu/I-TASSER/), Phyre2 (http://www.sbg.bio.ic.ac.uk/ phyre2/html/page.cgi?id=index) and Swiss-model (https://swissmodel.expasy.org/). All three tools found the closest available crystal structures for homology modelling had between just $14-32 \%$ amino acid identity to the query sequence (data not shown). This suggests that homology models produced for this protein sequence are unlikely to be representative of the true structure. 
The relationship between soil stratigraphy nomenclature and abiotic chemical/physical variables has been long established in the geological literature - and has also previously been considered in the context of Alpine glacial deposition (Birkland et al., 1979). In this study, we were able to confirm a clear differentiation between the designated soil horizon samples previously described by Mahaney et al. (2016) and the physical/chemical composition of the samples using PCA plots. The data form a framework for later comparison with the distribution of laccases in the same samples.

Our main objective in this study was to see if there was a connection between soil pedon classification and the distribution of bacterial laccases in a model soil ecosystem. We chose to look at bacterial laccases for a number of reasons: i) they are enzymes with diverse function. Some are required for intracellular endospore germination/formation processes, such as the Cot A proteins (Francisco et al., 2004), while there is clear evidence that the small three domain and typeB twodomain enzymes are extracellular enzymes are used for lignin degradation (Bugg et al., 2004); ii) The extracellular bacterial laccases are secreted by one taxon into the environment, but then can also benefit other components in a microbial ecosystem such as soil. As such, we might expect the distribution of these genes to be related to cooperative behaviours between different bacterial taxa in localised communities (West et al. 2006); iii) As potential industrial biocatalysts they are particularly useful, while also being structurally simple as single component enzymes - making them good candidates to demonstrate the potential for paleosol metagenome-mining as a source of useful functional genes (Call \& Mucke, 1997).

Looking at the differences in the distribution of the genes encoding five different 'classes' of enzymes, that are already established in the literature, two key observations become evident: Firstly, there does appear to be present distinct sub-populations of laccase enzymes in soil pedons from our data. Not only do the relative abundance of laccase genes in the stratified soils clearly demarcate between Ah, Bw and Cox soil horizons, but we also observed that the beta diversity 
between populations of laccase genes in soil horizons is suggestive of greater dissimilarity of gene populations between soil horizons in any individual paleosol than between geographical locations even when these locations are kilometres apart (such as between the site V10C and any of the G sites studied here). This is especially evident for the typeB two-domain and small three-domain enzyme groups that were generally abundant in all the soil pedons (Figure 3). Clearly, from the perspective of bacterial laccase gene function and phylogenetic diversity, we can say that Ah and Bw soil horizon - though just separated physically by centimetres - are fundamentally different environments. One explanation we can propose for this marked difference in laccase gene diversity across soil horizons down profile is their potential importance as 'public good' proteins in complex bacterial communities of heterotrophic bacteria that rely upon the degradation of plant-derived lignin as a carbon and energy source. The principal component analysis of the 27 physical parameters measured in the soil horizons (Figure 1) showed clear demarcation of the three types of soil horizon across all 18 soil pedons. However, differences between the populations of the most abundant typeB two-domain laccases and the small three-domain laccases across the boundary of the $\mathrm{Ah}$ and $\mathrm{Bw} / \mathrm{Cox}$ pedons follow a different distribution: clear dissimilarity is evident between Ah and Bw gene populations for PCoA1, whereas no dissimilarity is seen between the populations of these genes in the Bw and Cox horizons. This would support a hypothesis that biological and perhaps even societal factors consistently lead to polarisation of these groups of enzymes between Ah and Bw horizons. This conclusion is certainly speculative at this stage, but it does highlight the possibility of using paleosol horizon metagenome analysis of such 'public goods protein' functional genes for the study of developing field of bacterial sociobiology (Griffin et al., 2004). Critically, the different classes of laccase studied do not partition in an identical fashion between the pedons. For example, the CotA type three domain laccase gene populations differentiate as well between Bw and Cox soil horizons as they do between Ah and Bw horizons from the PCA analysis (Figure 3). Furthermore, the fact that $\operatorname{Cot} A$ enzymes are not likely to be public goods proteins could be important. Enzymes may 
have the same functionality but different roles in a bacterial community, and laccases in particular may serve a community function in soil microbial ecosystems (Freedman and Zak, 2015).

364 As initially noted, the use of metagenome gene-mining as a process to source new industrial enzymes is an important possibility for the generation of new biocatalysts. We wanted to demonstrate here that with our paleosol data set we could successfully obtain, clone and validate expression of novel typeB two-domain laccase enzymes. We chose to isolate genes for the most abundant 2D two component enzymes - that have not been studied extensively as biocatalytic enzymes - due to their relative novelty. The methodology developed here shows clearly that such enzymes can be readily obtained and assayed for enzyme activity. The observed activity against model substrates is consistent with other extracellular bacterial laccases of biotechnological importance (Couto et al., 2006).

\section{Acknowledgements}

374 We thank the REMEDIATE ITN project (BPK, CCRA), Invest Northern Ireland (JMY) and the

375 Commonwealth Scholarships Commission (SUD) for financial support. We also acknowledge a reviewer of the manuscript for useful suggestions. 
380 S1: Complete laccase ORF for which PCR primers were designed. This was assembled using the Megahit assembly approach described in the methods.

ATGAGCAATAGACGTGGCTTTTTGCGAAATATTCTCGCCGGAGCTGGCGCTATGGTTTCCGCGAGAGTTCTTT CAGCCCAAGAGACGGACACGTCTCATGGGATGCACGGAATGAAAATGAAAGGTAGGCAGGAGTCGGAGCGC GGCCACGGTTCTCCCGTGCTTATGGAAACGCCGGACGTTCCGCAACTTCCGTGGCGCATGGATGGGGGCGTA AAGGAATTCCATCTCATTGCCGAGCCGGTGAAACAGGAGATTTTTCCTGGCCGGATCGTTGACCTCTGGGGTT ACAACGCCAGCGCTCCGGGGCCGACGATTCAAGTCAACCAGGGCGATCGCGTTCGGATCATCGTGGACAACC ACCTTCCCGAAGCGACGTCGATGCACTGGCACGGCTTCGAAATCCCGAGCGAGATGGACGGAGCGCCCGGTT CGAGTCAAGACCCGATCCCTCCCGGGGGCCGCTTTGTCTATGAATTCACGCTCCACCAGGAAGGCACTTATTTC TACCACTCGCACATGGCGATGCAGGAAATGATGGGCATGATCGGCGCGTTCATCATGCATCCCAAGGAGCCA TACAAGCCGCGCGCCGATAAAGACTTCGCCATCATTATGCAGGAGTACGCCATCTTGCCGAACATCAAGGTCC CGAACTCCATGAACATGGAGTTCAACTGGCTTACCTTCAACGGAAAATCCGGTCCAGCCAACACTCCGCTCATT GTGCGGCACGGAGAGCGCGTCCGCATCCGCCTTATCAATCTGGGGATGGACCACCATCCGATCCACCTTCATG GGCACCAGTTCGTAGTTACAGGTACTGAAGGAGGCCGACAGCCCGAAACGACTTGGGGGCCGGGCAATACT GTTCTCGTTGGAGTCGCACAGTCCCGCGACGTGGAGTTCGTTGCCAACAACCCCGGCGACTGGATGCTGCACT GCCATCTTCCGCACCACATGATGAACCAGATGTCATCGATGGTCGGCCCGATGTCACGCCGAAATGGAATGCC TGCGGGTCTCGACATGGAGCGGGGCATGGGAATGCTGCGACAAGGAAGCGCGACGTCTGAGGAGAACGGT CCGAGCCTGGGTCGCGGAATGGGCGTCGGTTCGACAGCGGAGCAAACCATGTCGAATTCTCCGCTCAAAGCC GGGAGTCCGATGCAGCACCAAGACATGCCCGACATGCAGCAGCAAGGGATGCAGGGGAGGCAGCCCGACAA GCGCGATGACACGAAGGACGCGCATTGCTTGCCGGAGGATGCCTTGGTGGAAGGTATCATGATGGCGATGG ATCAAATGGTCGACAAACCTGAAAACTTCGGCCTGCGTCCCGGCTGGAGCGGCTTCATGGCAGGAATGATGA CGTTCGTACGCGTGCTGCCTCAAGACAAGTACGACCACAGCATGGAGCTTCGAAAAAAGCAGGAAGGCAATA AGCCAATGAAAATGGACATGCCGGAGATGGAGCACAAACATGAATAA

403

S2: Sequence statistics from total co-assembly and isolated laccase ORFS. Statistics are shown for both the complete co-assembly and the putative Laccase ORFs. Laccase hits were identified using the HMM 406 search pipeline as described in the text.

\begin{tabular}{|l|r|r|}
\hline & All_contigs & Laccase_hits \\
\hline \# contigs (>= 0 bp) & 7171198 & 323 \\
\hline \# contigs (>= 1000 bp) & 540891 & 151 \\
\hline \# contigs (>= 5000 bp) & 2869 & 0 \\
\hline \# contigs (>= 10000 bp) & 165 & 0 \\
\hline Total length (>= 0 bp) & 4127121895 & 316566 \\
\hline Total length (>= 1000 bp) & 804814220 & 199008 \\
\hline Total length (>= 5000 bp) & 19157720 & 0 \\
\hline $\begin{array}{l}\text { Total length (>= 10000 } \\
\text { bp) }\end{array}$ & 2202670 & 0 \\
\hline \# contigs & 3220893 & 283 \\
\hline Largest contig & 62040 & 2877 \\
\hline GC (\%) & 62.22 & 61.55 \\
\hline
\end{tabular}




\begin{tabular}{|l|r|r|}
\hline N50 & 775 & 1143 \\
\hline N75 & 614 & 912 \\
\hline L50 & 1102891 & 106 \\
\hline L75 & 2045807 & 180 \\
\hline
\end{tabular}

408

409 S3: Complete amino acid sequences of gene-mined laccases that were shown to have activity. These were obtained using PCR amplification using the V10_las primers as described in the text.

MSNRRGFLRNILAGAGAMASAKVLSAQEMHMSHGTQGMKGMKETERGHVSPTLVETPDVS QLSWRMGGSVKEFHLIAEPVKQEIFPGRIVDLWGYNGSAPGPTIQVNEGDRVRIIVDNHL PEATSMHWHGFEIPSAMDGAPGSSQDPIPPGGRFVYEFTLHQEGTYFYHSHMAMQEMMGM IGAFIMHPKEPHKPRADKDFAIIMQEYAILPNIKVPNSMNMEFNWLTFNGKAGPATTPLI VRHGDRVRVRLINLGMDHHPIHLHGHTFVVTGTEGGRQPQSTWSPGNTVLVGVAQSRDVE

417 FVATNPGDWMLHCHLPHHMMNQMSSMVGPMSRRNGTPAGLDMERGMGMLRQESATSEENG 418 PSLGRGMGMGSTAEQTVSNSPLKAVNPMQHKDMPNMQQPAMQMGKPDVSKDAISVPGFPQ PLQMDMPQMEHNQA

\section{$>$ LacB6}

MSNRRGFLRNILAGAGAMVSARVLSAQETDTSHGMHGMKMKGTRESESGHGSPMLVEMPD VAQLPWRLDGDVKEFHLIAEPVKQEIFPGRIVDLWGYNGSVPGPTIQVNQGDRVRIIVDN HLPEATSMHWHGFEIPNEMDGAPGSSQDPIPPGGRFVYEFTLHQEGTYFYHSHMAMQEMM GMIGAFIMHPKEPYKPRADKDFAIIMQEYAILPNIKVPNPMNMEFNWLTFNGKAGPATTP LIVRHGERVRIRLINLGMDHHPIHLHGHQFVVTGTEGGRQPQSTWGPGNTVLVGVAQSRD VEFVASNPGDWMLHCHLPHHMMNQMSSMVGPMSRRNEMPAGLDMERGMGMLRQGSATSEE NGPSLGRGMGVGSTAEQTMSNSPLKAENPMQHQDMPDMQPQGMQMGNPDVSKDANSVPGF PQDAFMEGPMMAMDQMVDKPENFGLRPGWSGFMAGMMTFVRVLPQDKYNQIMELRKKQEG NKPMKMDMPEMEHKHE

\section{$>$ LacC12}

MSNRRGFLRNILAGAGAMASAKVLSAQEMDMSHGMQGMKMKGVKKSEHAHASRMLVETPD VAQLPWRMEGNVKEFHLIAEPVKQEIFPGRVVDLWGYNGSAPGPTIQVNQGDRVRIIVEN RLPEATSMHWHGFEVPNEMDGAPGSSQDPIPPGGRFVYEFTLHQEGTYFYHSHMAMQEMM GMIGAFVMRPKQAYRPRVDHDFAIILQEYAILPNISVPNSMNMEFNWLTFNGKAGPATTP LIVRQGERVRIRLINLGMDHHPIHLHGHQFVVTGTEGGRQPESTWGPGNTVFVGVAQSRD IEFVASNPGDWMLHCHLPHHMMNQMSSNVGPMTRRNGIPAGLDMERGMGMLRQGSATSEE HGPSLGRGMGVGSTFEQRMSNSPLKAGSPMQHQGMQMGKPDVSKDANSVPGFPQDAFMEG PMMAMDQRVDKPENFGLRPGWSGFMAGMMTFVRVLPQDKYDHIMELRKKQEGNKPMKMDM PEMEHKHE

\section{$>$ LacC15}

MSNRRGFLRNILAGAGAMASAKVLSAQEMEMSHGMQGMKMKGVKKSERDHASRMLVETPD VAQLPWRMDGSVKEFHLIAEPVKQEIFPGRVVDLWGYNGSVPGPTIQVNQGDRVRIIVDN HLPEATSMHWHGFEIPNEMDGAPGSSQDPIPPGGRFVYEFTLHQEGTYFYHSHMAMQEMM GMIGAFIMHPKEPYKPRSDKDFAIIMQEYAILPNIKVPNSMNMEFNWLTFNGKAGPATTP LIVRHGDRVRVRLINLGMDHHPIHLHGHQFVVTGTEGGRQPQSTWGPGNTVLVGVAQSRD VEFVASNPGDWMLHCHLPHHMMNQMSSMVGPMSRRNGMPAGLDMERGMGMLRQGSAMSEE NGPSLGRGMGVGSTAEQTMSNSPLKAGNPMQHQAMPNMQQQGMKMGKPDVSKDANSVPGF 
S4: Laccase taxonomic distribution by type Phylum level

457

458

459

460

461

462

463

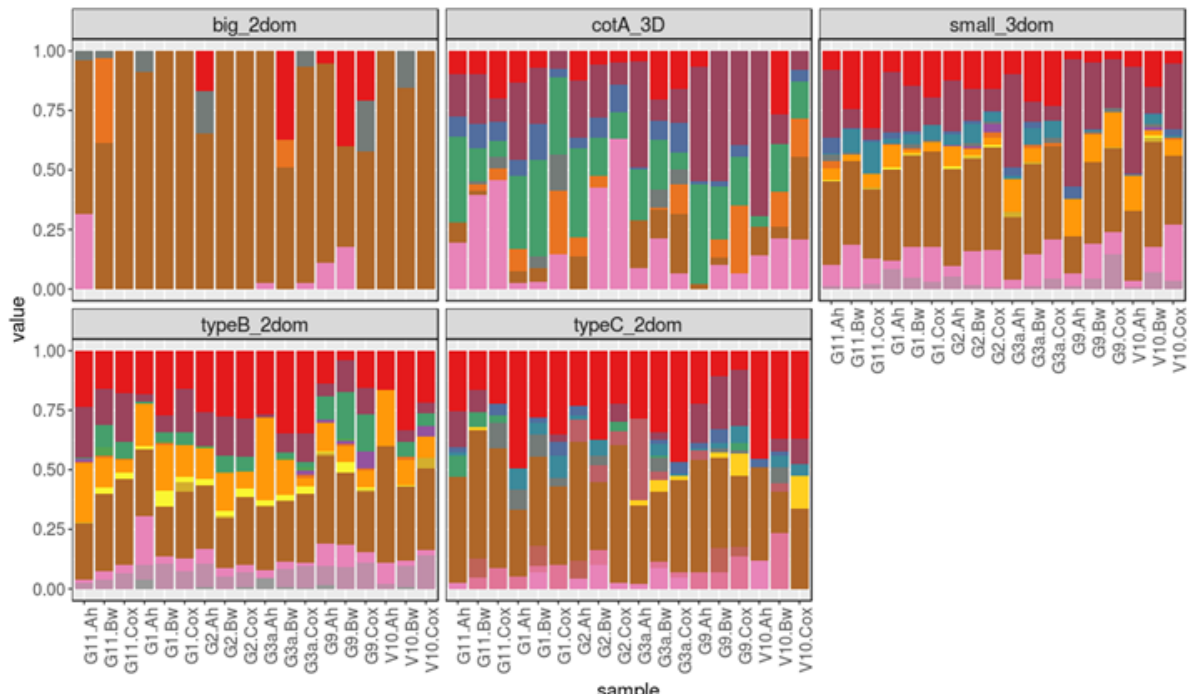

sample variable

Acidobacteria

Actinobacteria

Bacteria candidate phyla

Bacteroidetes

Chloroflexi

Cyanobacteria/Melainabacteria group

Deinococcus-Thermus

Euryarchaeota

Firmicutes

Gemmatimonadetes

Nitrospirae

Opisthokonta
Planctomycetes

Planctomycetes

Spirochaetes

Thaumarchaeota

Unclassified Bacteria

Verrucomicrobia

Viridiplantae

Taxonomic profile for each class of laccase genes Isolated. Laccase gene sequences were taxonomically annotated using Kaiju (Menzel et al., 2016), as described in the main methods section of the paper. See figure 4 for origin of the five laccase type designations.

\section{S.5. Map of sampling sites used in the study (from Young et al., 2019).}

A

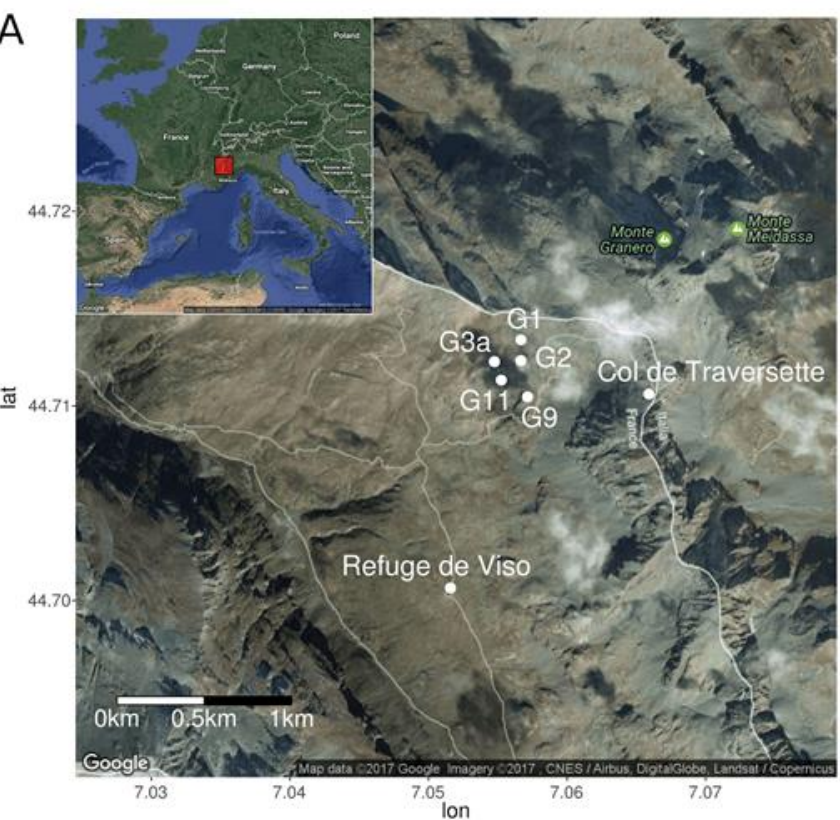

B
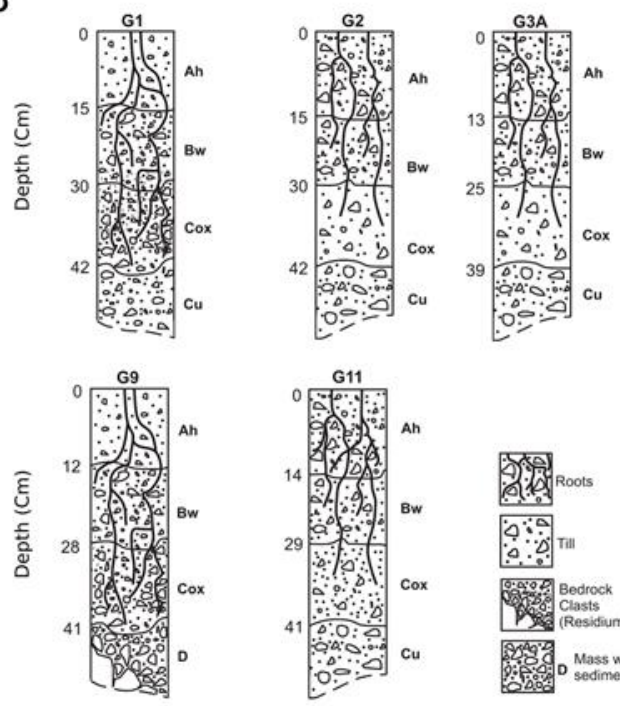
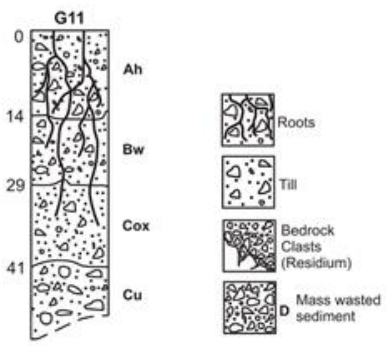

Overview of Sampling sites and soil stratigraphy. Panel A: Satellite map of sampling area. Panel B: 
the top of each profiles, depth in centimetres is displayed on the left and soil horizon classification is displayed on the right of each profile.

\section{REFERENCES}

Ausec, L., Zakrzewski, M., Goesmann, A., Schlüter, A., Mandic-Mulec, I., 2011. Bioinformatic analysis reveals high diversity of bacterial genes for laccase-like enzymes. PLoS ONE. 6(10), e25724

Ausec, L., Berini, F., Casciello, C., Cretoiu, M.S., Van Elsas, J.D., Marinelli, F. and Mandic-Mulec, I., 2017. The first acidobacterial laccase-like multicopper oxidase revealed by metagenomics shows high salt and thermo-tolerance. Applied Microbiology and Biotechnology, 101(15), pp. 6261-6276.

Bertani, G. 1951. Studies on lysogenesis. I. The mode of phage liberation by lysogenic Escherichia coli. J. Bacteriol. 62, 293-300

Birkland, P.W., Colman, S,M., Burke, R.M, Shroba, R.R., Meierding, T.C., 1979. Nomenclature of alpine glacial deposits, or, What's in a name? Geology, 7 ,pp. 532-536.

Bugg, T.D.H., Ahmad, M., Hardiman, E.M., Singh, R., 2011. The emerging role for bacteria in lignin degradation and bio-product formation. Current Opinion in Biotechnology, 22(3), pp. 394-400.

Bushnell B. (2015). BBMap short-read aligner, and other bioinformatics tools. Available from sourceforge net/projects/bbmap.

Call, H.P., Mucke, I., 1997. History, overview and applications of mediated lignolytic systems, especially laccase-mediator-systems (Lignozym ${ }^{\circledR}$-process). Journal of biotechnology. 53 (2-3), pp. 163-202

Chauhan, P.S., Goradia, B. And Jha, B., 2018. Optimization and up scaling of ionic liquid tolerant and thermo-alkali stable laccase from a marine Staphylococcus arlettae S1-20 using tea waste. Journal of the Taiwan Institute of Chemical Engineers, 86, pp. 1-8.

Chauhan, P.S. And Jha, B., 2018. Pilot scale production of extracellular thermo-alkali stable laccase from Pseudomonas sp. S2 using agro waste and its application in organophosphorous pesticides degradation. Journal of Chemical Technology and Biotechnology, 93(4), pp. 1022-1030.

Couto, S. R., Herrera, J.L.T., 2006. Industrial and biotechnological applications of laccases: a review. Biotechnology advances 24(5), 500-513.

Cragg, S.M., Beckham, G.T., Bruce, N.C., Bugg, T.D., Distel, D.L., Dupree, P., Etxabe, A.G., Goodell, B.S., Jellison, J., McGeehan, J.E., McQueen-Mason, S.J., 2015. Lignocellulose degradation mechanisms across the Tree of Life. Current Opinion in Chemical Biology. 1(29), pp.108-119.

Dixon, P., 2003. VEGAN, a package of $R$ functions for community ecology. Journal of Vegetation Science, 14(6), pp. 927-930.

Durão, P., Chen, Z., Fernandes, A.T., Hildebrandt, P., Murgida, D.H., Todorovic, S., Pereira, M.M., Melo, E.P. and Martins, L.O., 2008. Copper incorporation into recombinant CotA laccase from Bacillus 
503

504

505

506

507

508

509

510

511

512

513

514

515

516

517

518

519

520

521

522

523

524

525

526

527

528

529

530

531

532

533

534

535

536

537

538

539

540

subtilis: Characterization of fully copper loaded enzymes. Journal of Biological Inorganic Chemistry, 13(2), pp. 183-193.

Fang, Z., Li, T., Wang, Q., Zhang, X., Peng, H., Fang, W., Hong, Y., Ge, H., Xiao, Y., 2011, A bacterial laccase from marine microbial metagenome exhibiting chloride tolerance and dye decolorization ability. Applied microbiology and Biotechnology. 89(4), pp1103-1110.

Francisco, J.E., Marçal, D., Martins, L.O., Grenha, R., Henriques, A.O., Lindley, P.F., Carrondo, M.A., 2004. Substrate and Dioxygen Binding to the Endospore Coat Laccase from Bacillus subtilis. Journal of Biological Chemistry, 279 (22), pp. 23472-23476.

Freedman, Z.B. and Zak, B.R., 2015. Atmospheric N deposition alters connectance, but not functional potential among saprotrophic bacterial communities. Molecular Ecology. 24(12), pp3170

Godornes, C., Leader, B.T., Molini, B.J., Centurion-Lara, A., Lukehart, S.A. 2007, Quantitation of rabbit cytokine mRNA by real-time PT-PCR. Cytokine 38(1), 1-7

Griffin, A.S., West, S.A., Buckling, A. 2004, Cooperation and competition in pathogenic bacteria. Nature 430, 1024-1027

Guan, Z., Song, C., Zhang, N., Zhou, W., Xu, C., Zhou, L., Zhao, H., Cai, Y. and Liao, X., 2014. Overexpression, characterisation, and dye-decolorizing ability of a thermostable, pH-stable, and organic solvent-tolerant laccase from Bacillus pumilus W3. Journal of Molecular Catalysis B: Enzymatic, 101, pp. 1-6

Harris, E.D., 2000. Cellular copper transport and metabolism. Annual Review of Nutrition, 20, pp. 291310

Hyatt, D., Chen, G-L., Locascio, P.F., Land, M.L., Larimer, F.W., Hauser, L.J., 2010. Prodigal: prokaryotic gene recognition and translation initiation site iden0tification. BMC Bioinformatics 11, pp119.

Ihssen, J., Reiss, R., Luchsinger, R., Thöny-Meyer, L. and Richter, M., 2015. Biochemical properties and yields of diverse bacterial laccase-like multicopper oxidases expressed in Escherichia coli. Scientific Reports, 5 .

Jacquiod, S., Demaneche, S., Franqueville, L., Ausec, L., Xu, Z., Delmont, T.O. et al., 2014. Characterization of new bacterial catabolic genes and mobile genetic elements by high throughput genetic screening of a soil metagenomic library. Journal of Biotechnology, 190(20), pp.18-29.

Jones, R.T., Robeson, M.S., Lauber, C.L., Hamady, M., Knight, R., Fierer, N., 2009. A comprehensive survey of soil acidobacterial diversity using pyrosequencing and clone library analyses. The ISME Journal. 3, pp. 442-453

Koroleva, O.V., Stepanova, E.V., Binukov, V.I., Timofeev, V.P. and Pfeil, W., 2001. Temperatureinduced changes in copper centers and protein conformation of two fungal laccases from Coriolus hirsutus and Coriolus zonatus. Biochimica et Biophysica Acta - Protein Structure and Molecular Enzymology, 1547(2), pp. 397-407.

Kruskal, W.H., Wallis, W.A., 1952. Use of ranks in one-criterion variance analysis. Journal of the Americam Statistical Association. 47: 583-621 
541 Kumar,S., Stecher, G., Tamura, K., 2016. MEGA7: Molecular Evolutionary Genetics Analysis Version

5427.0 for Bigger Datasets. Molecular Biology and Evolution. 33 (7), pp 1870-1874

543 Li, D., Luo, R., Liu, C.M., Leung, C.M., Ting, H.F., Sadakane, K., Yamashita, H., and Lam, T.W., 2016.

544 MEGAHIT v1. 0: A fast and scalable metagenome assembler driven by advanced methodologies and 545 community practices. Methods, 102, pp3-11

546 Lu, L., Wang, T.-., Xu, T.-., Wang, J.-., Wang, C.-. and Zhao, M., 2013. Cloning and expression of thermo547 alkali-stable laccase of Bacillus licheniformis in Pichia pastoris and its characterization. Bioresource 548 technology, 134, pp. 81-86.

549 Machczynski, M.C., Vijgenboom, E., Samyn, B., Canters, G.W., 2009. Characterization of SLAC: A small 550 laccase from Streptomyces coelicolor with unprecedented activity. Protein Science. 13(9), pp 23885512397

552 Mahaney WC, Somelar P, Dirszowsky RW, Kelleher B, Pentlavalli P, McLaughlin S, et al. (2016). A 553 Microbial Link to Weathering of Postglacial Rocks and Sediments, Mount Viso Area, Western Alps, 554 Demonstrated through Analysis of a Soil/Paleosol Bio/Chronosequence. Journal of Geology, 124, 149$555 \quad 169.1$

556 Martins, L.O., Durão, P., Brissos, V., Lindley, P.F., 2015. Laccases of prokaryotic origin: enzymes at the 557 interface of protein science and protein technology. Cellular and molecular life sciences. 72(5) pp.91155822.

559 McKnight, C.J., Briggs, M.S. and Gierasch, L.M., 1989. Functional and nonfunctional LamB signal 560 sequences can be distinguished by their biophysical properties. Journal of Biological Chemistry, 561 264(29), pp. 17293-17297.

562 Menzel, P., Ng, K.L., Krogh, A., Marth, G., Lipman, D., 2016. Fast and sensitive taxonomic classification 563 for metagenomics with Kaiju. Nature Communications. 7: pp11257.

564 Mohammadian, M., Fathi-Roudsari, M., Mollania, N., Badoei-Dalfard, A. and Khajeh, K., 2010. 565 Enhanced expression of a recombinant bacterial laccase at low temperature and microaerobic 566 conditions: Purification and biochemical characterization. Journal of Industrial Microbiology and 567 Biotechnology, 37(8), pp. 863-869.

568 Mollania, N., Heidari, M. and Khajeh, K., 2018. Catalytic activation of Bacillus laccase after temperature 569 treatment: Structural \& biochemical characterization. International journal of biological 570 macromolecules, 109, pp. 49-56.

571 Muyzer, G., De Waal, E.C. \& Uitterlinden, A.G. 1993. Profiling of complex microbial populations by 572 denaturing gradient gel electrophoresis analysis of polymerase chain reaction-amplified genes coding 573 for 16S rRNA. Applied and Environmental Microbiology, 59(3), pp. 695-700.

574 Nakamura, K., Kawabata, T., Nobuhiro Go, K.Y., 2003. Novel types of two-domain multi-copper 575 oxidases: possible missing links in the evolution. FEBS Letters, 553, pp1873-3468

576 NCBI Resource Coordinators, 2017. Database Resources of the National Center for Biotechnology 577 Information. Nucleic Acids Research. 45: D12-D17

578 Oksanen J, Blanchet FG, Kindt R, Legendre P, Minchin PR, O'hara RB, Simpson GL, Solymos P, Stevens 579 MH, Wagner H (2011). vegan: Community ecology package. $R$ package version. 2011, pp.117-118. 
580 Papinutti, L., Dimitriu, P. and Forchiassin, F., 2008. Stabilization studies of Fomes sclerodermeus 581 laccases. Bioresource technology, 99(2), pp. 419-424.

582 R Development CoreTeam, 2011. A language and environment for statistical computing. R Foundation 583 for Statistical Computing, Vienna. http://www.R-project.org

584 Suzuki, M.T., Taylor, L.T. \& DeLong, E.F. 2000, "Quantitative analysis of small-subunit rRNA genes in 585 mixed microbial populations via 5'-nuclease assays", Applied and Environmental Microbiology, 66(11), 586 pp. 4605-4614.

587 Torsvik, V., Jostein, G., Daae. F.L., 1990. "High diversity in DNA of soil bacteria." Applied and 588 environmental microbiology 56(3), pp. 782-787.

589 Vulpe, C.D. and Packman, S., 1995. Cellular copper transport. Annual Review of Nutrition, 15, pp. 293$590 \quad 322$

591 Wagner, G.P., Kin, K., Lynch, V.J., 2012. Measurement of mRNA abundance using RNA-seq data: RPKM 592 measure is inconsistent among samples. Theory Biosciences. 131, pp.281-285.

593 West, S.A., Griffin, A.S., Gardner, A., Diggle, S.P., 2006. Social evolution theory for microorganisms. 594 Nature Reviews Microbiology, 4, pp. 597-607.

595 Yang, Q., Zhang, M., Zhang, M., Wang, C., Liu, Y., Fan, X., Li, H., 2018. Characterization of a Novel, Cold596 Adapted, and Thermostable Laccase-Like Enzyme With High Tolerance for Organic Solvents and Salt 597 and Potent Dye Decolorization Ability, Derived From a Marine Metagenomic Library. Frontiers in 598 Microbiology. 9, pp.2998

600 Ye, M., Li, G., Liang, W.Q. and Liu, Y.H., 2010. Molecular cloning and characterization of a novel 601 metagenome-derived multicopper oxidase with alkaline laccase activity and highly soluble expression. 602 Applied Microbiology and Biotechnology, 87(3), pp. 1023-1031.

603 Young, J.M., Skvortsov, T,. Kelleher, B.P., Mahaney, W.C., Somelar, P., Allen, C,C,R, 2019. Effect of soil 604 horizon stratigraphy on the microbial ecology of alpine paleosols. Science of The Total Environment. 605 657, pp. 1183-1193

606 


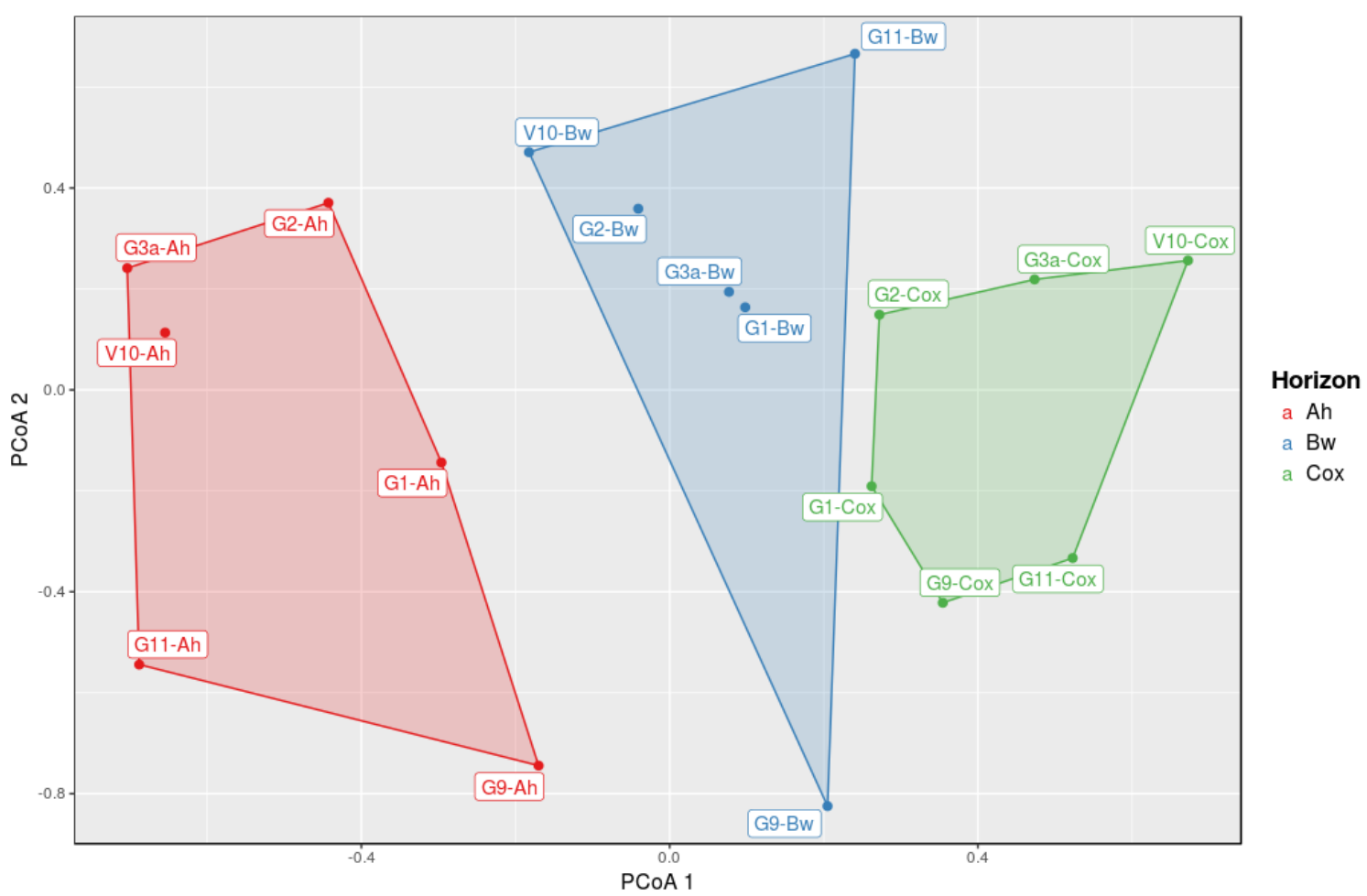

Figure 1. Principal coordinates analysis, of Alpine soil physical-chemical characteristics. A total of 26 Soil Abiotic variables were compared, (supplementary table 1.). Variables were log transformed and normalised such that the sum of squares for each sample $=1$. Sample dissimilarities were calculated by their Euclidean distances. PcoA was performed using the capscale function in the package vegan (Oksanen et al., 2016) in R version 3.4.1 ( $R$ Core Team, 2011), The first two principle co-ordinate axes were used to ordinate the samples in $2 d$ space. Samples are coloured by their soil horizon classification and convex hulls are displayed for each horizon. 


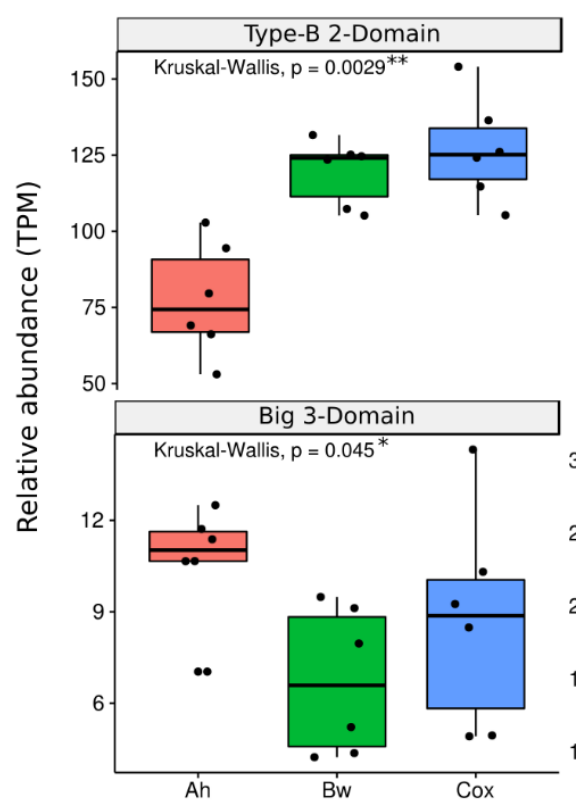

610

611

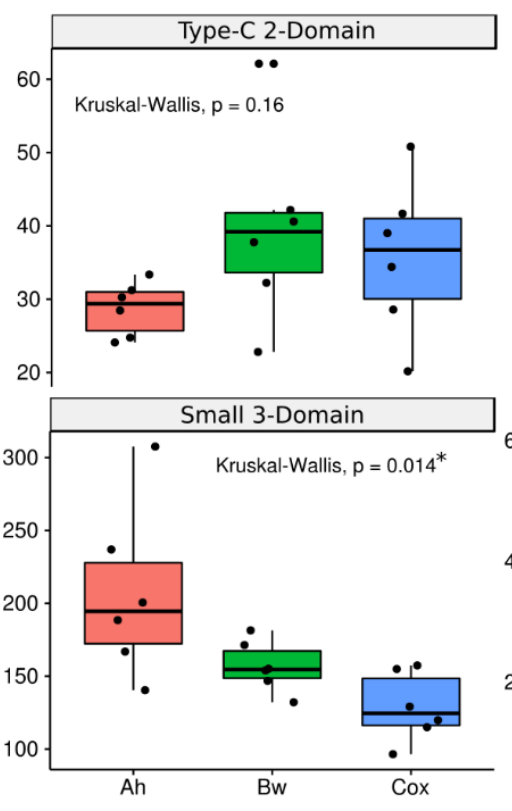

Soil Horizon

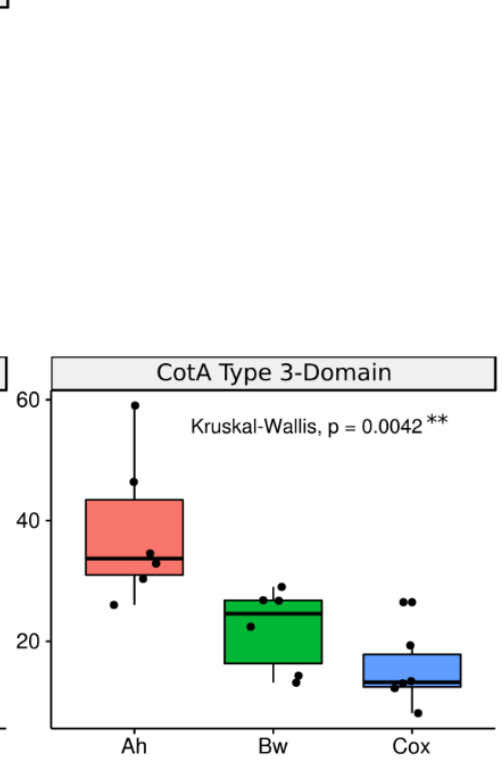




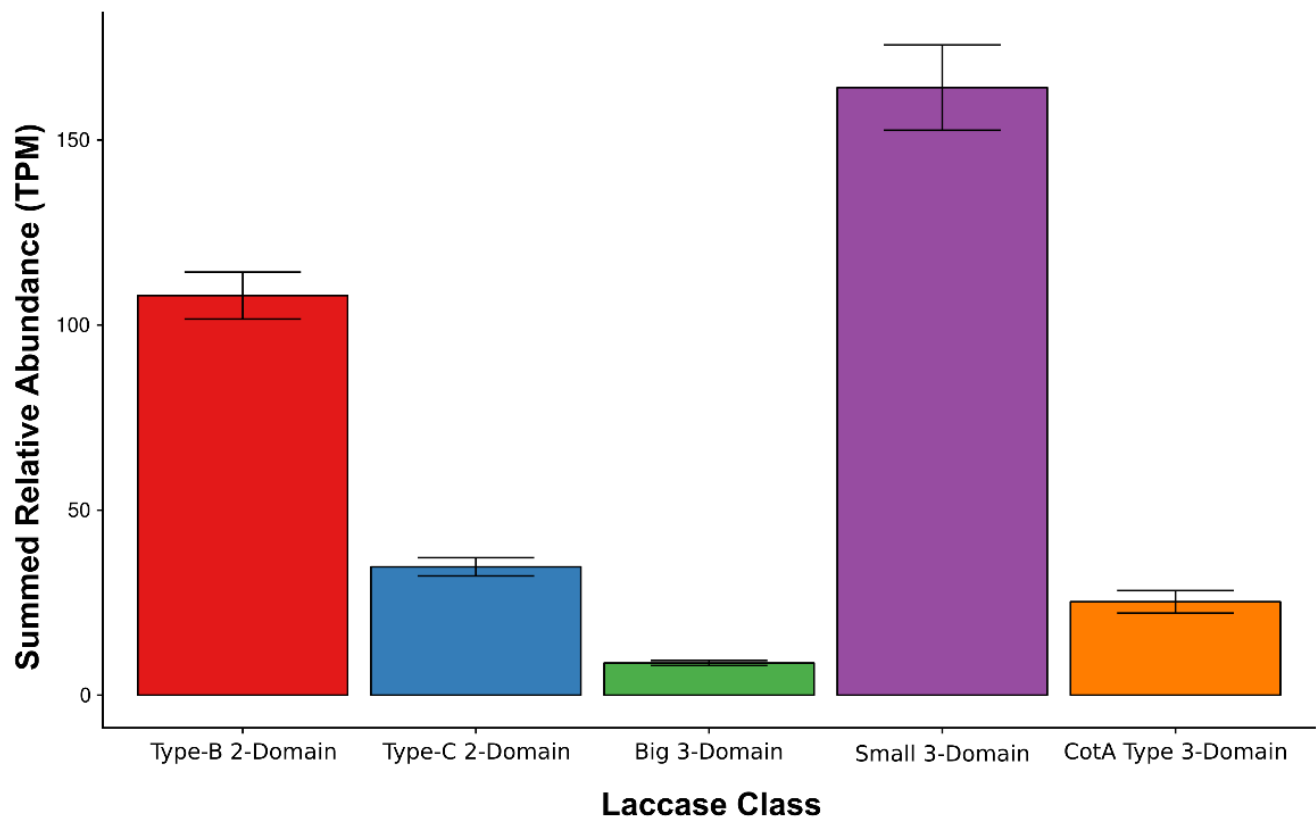

622

623 Figure 3. Total relative abundance for each of the 323 putative identified laccase genes was performed 624 across all sample microbiomes. Error bars represent standard error of the mean abundance across all 625 samples. The laccase genes identified in each sample were annotated using the package Kaiju (Menzel 626 et al., 2016). Statistical analysis of each enzyme subgroup across the metagenome datasets was 627 performed using Kruskal-Wallis one way ANOVA (Kruskal \& Wallis, 1952). The distinction between 628 type B and C 2-domain laccase is from Nakuamura et al. (2003). The designation of small and large 3629 domain laccases comes from Machczynski et al. (2009). The CotA 3-Domain laccases were described 630 by Martin et al. (2015). 

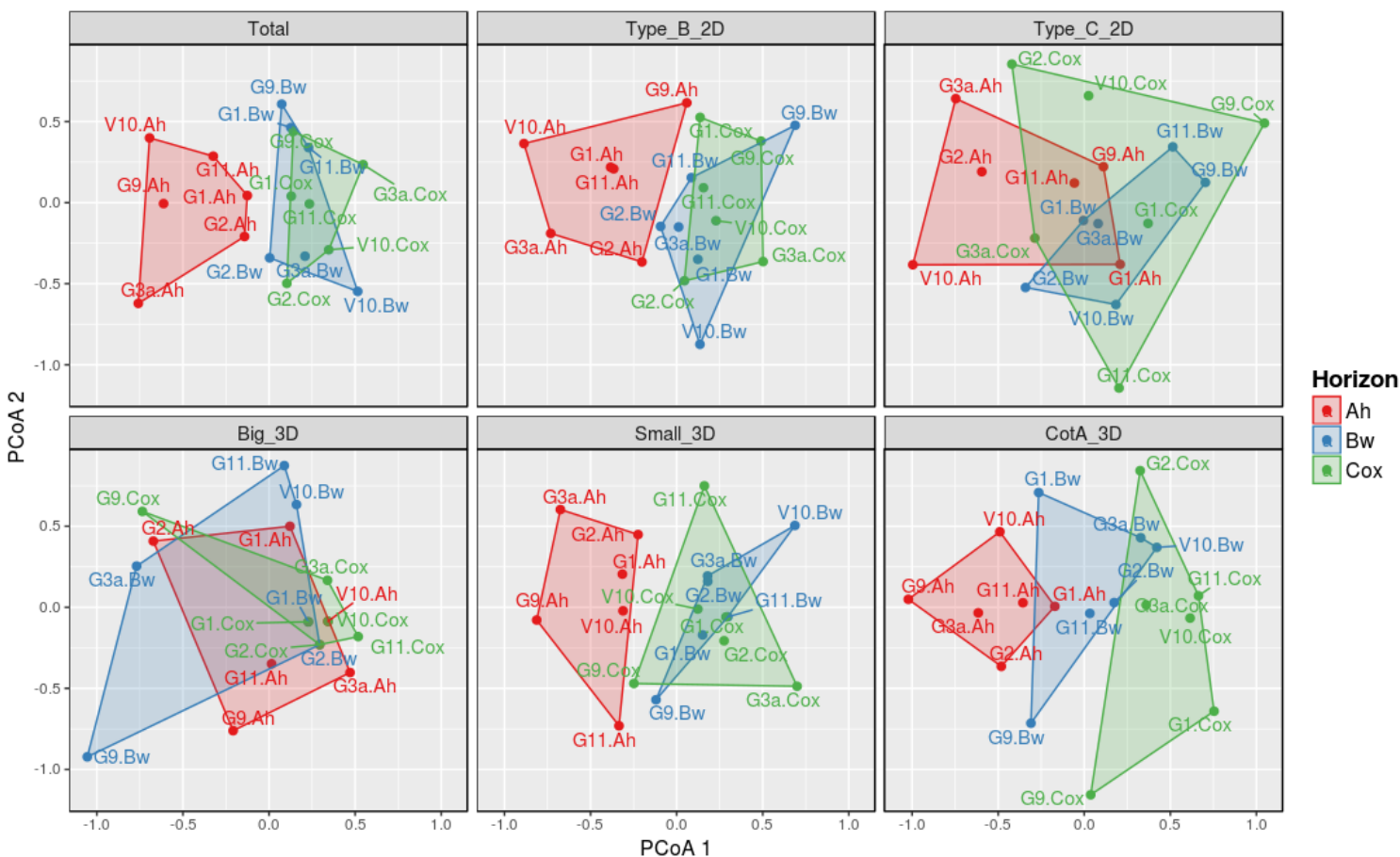

Figure 4. PCA plots for each laccase class abundance plus summed abundances (Phylum level): Laccase genes were taxonomically classified at the Phylum level using the lowest common ancestor algorithm. For each sub-class, Percentage abundances were normalized by Hellinger transformation, sample dissimilarities were calculated by their Euclidean distances. PcoA was performed using the capscale function in the package vegan (Oksanen etal., 2016) in R version 3.4.1 (R Core Team, 2011), The first two principle co-ordinate axes were used to ordinate the samples in $2 \mathrm{~d}$ space. Samples are coloured by their soil horizon classification and convex hulls are displayed for each horizon. 


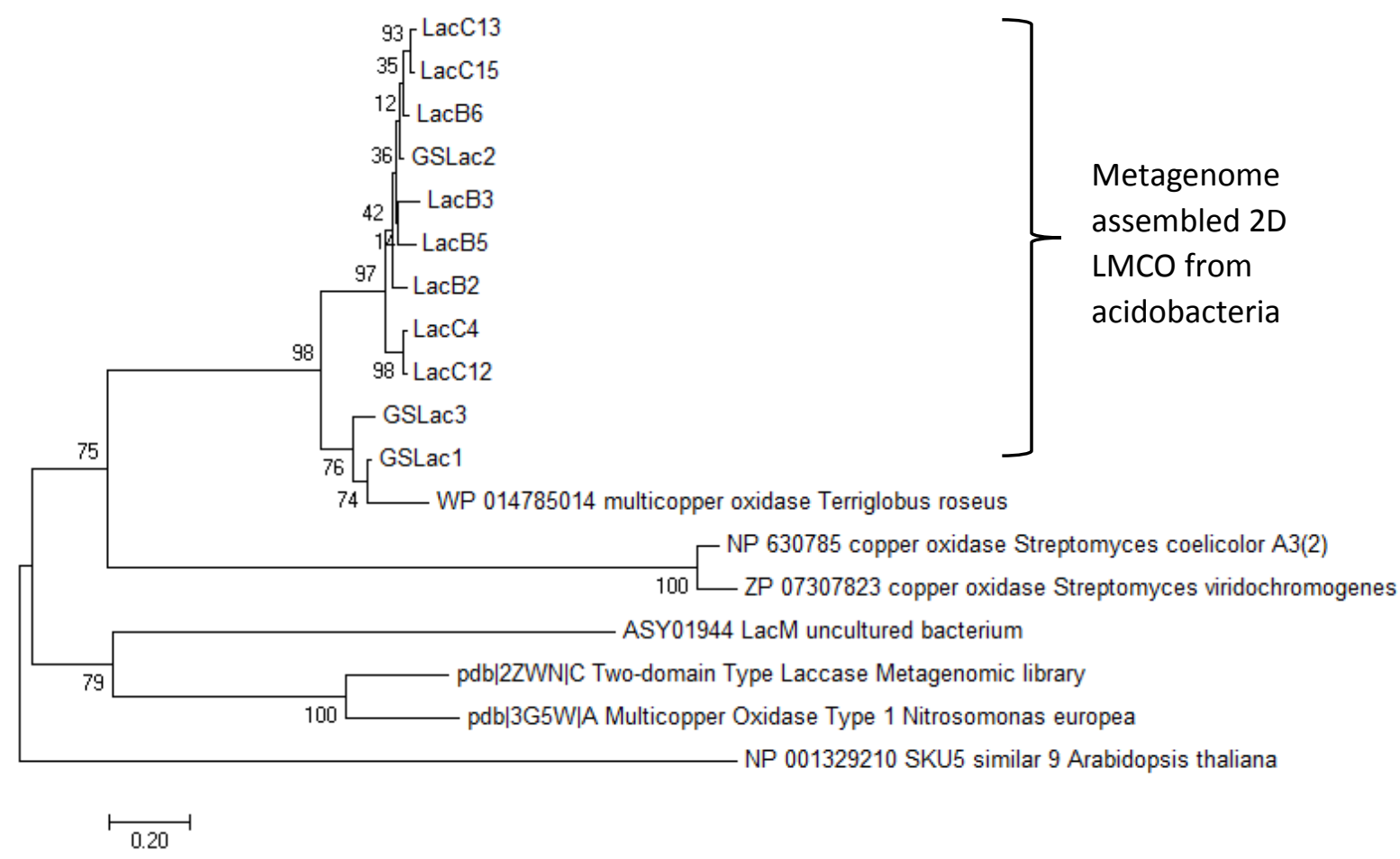

Figure 5. Maximum likelihood phylogenetic tree of alpine metagenome-derived LMCOs with reference sequences of bacterial two domain laccases that demonstrated activity. The sequences are type B 2 domain laccases amplified using the V10_lac PCR primers as described in the text, against DNA exracted from separate V10 Bw and Cox samples (hence designation B or C). Sample LacM (Ausec et al., 2017) was also included as the first acidobacterial metagenome-derived LMCO, though it is a three domain laccase. The tree was drawn using Mega 7.0 (Kumar et al., 2016). The reference sequence shown were downloaded from the NCBI database. The GSLac sequences are representatives of the metagenome-assembled putative laccase genes referred to in 3.2, while the LacB and C samples are sequences obtained after PCR amplification from Bw and Cox horizons I section 3.3. 


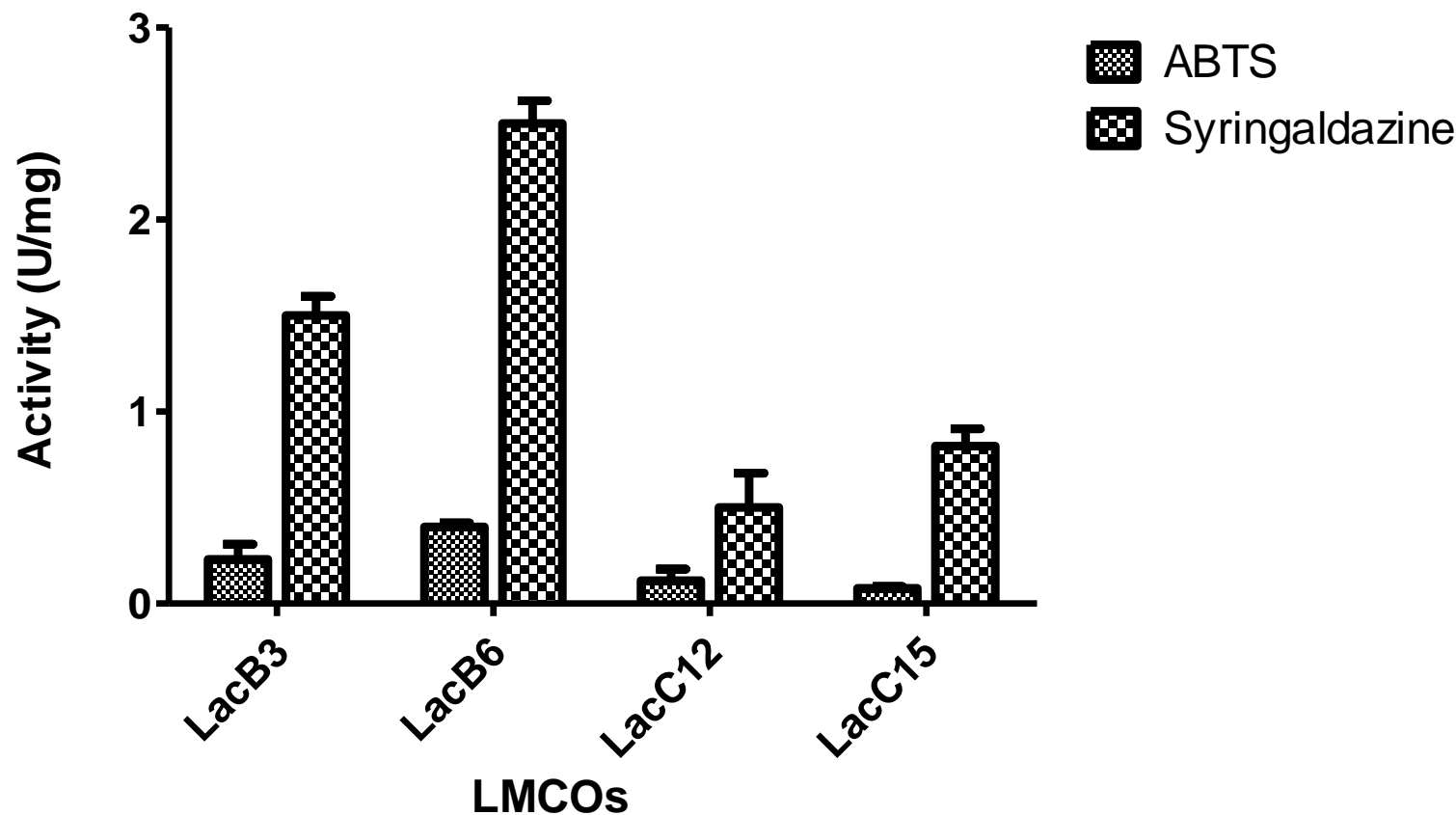

656 Figure 6: Specific activities of heat treated partially purified metagenome-derived laccase-like multi 657 copper oxidases (LMCOs) from E.coli clone cell free extracts. The enzyme activity against these 658 substrates was also compared with a vector control for the E.coli expression system (data not shown) 659 where little activity was detectable $(<0.01 \mathrm{U} / \mathrm{mg}$ for both substrates). Activity measurements are 660 measurements of triplicate analysis (error bars show standard deviation). See methods section for 661 assay details. 


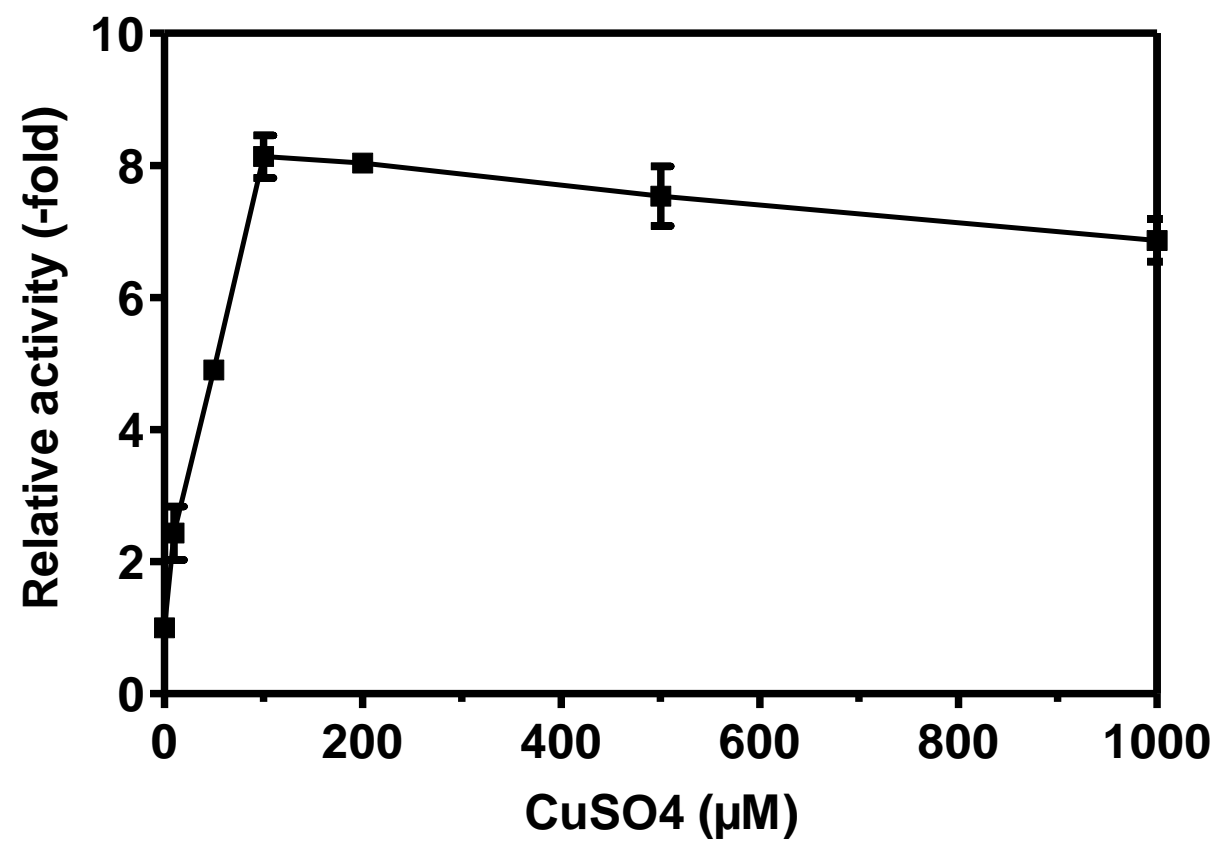

664

Figure 7: Effect of increasing concentrations of $\mathrm{CuSO}_{4}$ on the cloned laccase LacB6. Values are fold increase at different concentrations relative to the specific activity of $2.5 \mathrm{U} / \mathrm{mg}$ recorded in the absence of copper, where relative activity is set as 1 . Activity measurements are measurements of 